JURNAL KETAHANAN NASIONAL

ISSN: 0853-9340 (Print), ISSN: 2527-9688 (Online)

Online sejak 28 Desember 2015 di: http://jurnal.ugm.ac.id/JKN

VOLUME 23

No. 1, 27 April 2017

Halaman 49-67

\title{
Optimalisasi Peran Rimbawan Muda Dalam Pengelolaan Taman Nasional Gunung Ciremai Dan Implikasinya Terhadap Ketahanan Wilayah (Studi di Balai Taman Nasional Gunung Ciremai Kuningan, Jawa Barat)
}

\author{
Nurhalida Yogaswara \\ Pecinta Alam Rimba Kamuning \\ Email: yogaswaranurhalida92@yahoo.com
}

Edhi Martono

Fakultas Pertanian UGM

Email: armaidy@ugm.ac.id

Djaka Marwasta

Fakultas Geografi

Email: jakamar@ugm.ac.id

\begin{abstract}
This research examined the optimization of the role of young foresters in the management of Ciremai Mountain National Park (TNGC) and its implications for regional resilience (Studies in the National Park of Mount Ciremai Kuningan, West Java). The purpose of this research aimed to analyzed the optimization of the role of the young foresters in the management of TNGC, as well as to analyzed the implications of optimization the role of a young forester resilience in the region surrounding villages and areas along TNGC itself.

Descriptive qualitative had been used and the data was collected based on in-depth interviews with research participants and deeper observation in the field. And also the data relied thoroughly on published data and academic journals or papers and also documentation. Data analysis techniques in this study, namely: 1) data reduction, presentation of data, Interpretation, and withdrawal conclusion.

The results showed that linked to optimization of the role of young foresters in conservation management efforts TNGC still seemed to clashed with the economic needs of society that had not been completely fulfilled by switching professions to became the organizer and environmental services since Mount Ciremai in charge as a National Park. Related to optimized the role of a young forester implications for the resilience of the region there was still an imbalance in the respective aspects such as ecological, economic, social and cultural rights of rural areas around the region and from the region TNGC itself.
\end{abstract}

Keywords: Optimization Management, Young Foresters, Regional Resilience

\begin{abstract}
ABSTRAK
Penelitian ini mengkaji tentang optimalisasi peran rimbawan muda dalam pengelolaan Taman Nasional Gunung Ciremai (TNGC) dan implikasinya terhadap ketahanan wilayah (Studi di Balai Taman Nasional Gunung Ciremai Kuningan Jawa Barat). Adapun tujuan dalam penelitian yaitu untuk menganalisis optimalisasi peran rimbawan muda dalam pengelolaan TNGC, serta untuk menganalisis implikasi optimalisasi peran rimbawan muda terhadap ketahanan wilayah di desa sekitar TNGC dan wilayah kawasan TNGC itu sendiri.
\end{abstract}


Metode yang digunakan oleh peneliti dalam penelitian ini adalah metode deskriptif kualitatif. Teknik pengumpulan data dilakukan dengan wawancara mendalam, dengan observasi lapangan, jurnal akademik dan dokumentasi. Teknik analisis data dalam penelitian ini, adalah reduksi data, penyajian data, interpretasi, dan penarikan kesimpulan.

Hasil penelitian menunjukkan bahwa terkait optimalisasi peran rimbawan muda dalam upaya pengelolaan kawasan konservasi TNGC tampaknya masih berbenturan dengan kebutuhan ekonomi masyarakat yang belum sepenuhnya tercukupi dengan beralih profesi menjadi pengelola wisata dan jasa lingkungan sejak Gunung Ciremai di tetapkan sebagai Taman Nasional. Terkait dengan implikasi optimalisasi peran rimbawan muda terhadap ketahanan wilayah, masih terdapat ketidakseimbangan di berbagai aspek seperti hak-hak masyarakat sekitar atas ekologi, ekonomi, sosial dan budaya di sekitar wilayah dan dari wilayah TNGC sendiri.

\section{Kata Kunci: Optimalisasi Pengelolaan TNGC, Rimbawan Muda, Ketahanan Wilayah}

\section{PENGANTAR}

Era pembangunan dewasa ini yang begitu cepat, menjadikan hutan menempati posisi dan peranan strategis, baik dalam menunjang aspek ekonomi, sosial, maupun ekologis. Bahkan secara global hutan tropis di Indonesia telah menjadi tumpuan untuk dapat berfungsi dan berperan lebih meningkatkan lagi kesejahteraan umat manusia. Karena hutan bukanlah sekadar kumpulan pohon atau suatu unsur yang berdiri sendiri secara bebas, tetapi merupakan suatu sistem yang selalu terkait dengan alam lingkungannya dan membentuk ekosistem. Sebagian dari itu terdapat fungsi yang bersifat preventif ekologis, seperti mencegah banjir dan erosi, mengatur tata air, menjaga kesuburan tanah, dan melindungi alam hayati serta alam khas (Hidayat, 2015).

Peran ekonomi kehutanan menjadi makin substansial karena karakteristik dunia usahanya yang mampu membangun pusatpusat pertumbuhan dan perkembangan ekonomi daerah-daerah terpencil di pedalaman. Dengan jumlah penduduk Indonesia yang bertambah sehingga faktor demografi penting menjadi bahan pertimbangan bagi pemerintah dalam menentukan arah dan kebijakan pembangunan kehutanan nasional. Dewasa ini, justru sedang menghadapi berbagai permasalahan dan tantangan yang sangat berat dan kompleks. Berbagai malpraktek pengelolaan dan pemanfaatan hutan dewasa ini justru mendominasi dalam praktek pengelolaan hutan. Meningkatnya praktek perambahan, penebangan liar, penyelundupan kayu, konflik sosial sehingga inkonsistensi kebijakan pemerintah telah menyebabkan sektor kehutanan mengalami keterpurukan. Kondisi tersebut secara nyata telah mengancam keberlanjutan peran ekonomi dunia usaha kehutanan serta kelestarian sumber daya hutan. Diperlukannya kesadaran sekaligus kesepahaman para pihak akan sebuah konsep revitalisasi yang akan mampu mewujudkan kebangkitan kehutanan nasional di masa yang akan datang (Soendjoto, 2010).

Berdasarkan keputusan Menteri Kehutanan Nomor: K.424/Menhut-11/2004 bahwa berdasarkan surat Keputusan Menteri Kehutanan Nomor 195/Kpts-II/2003 Tanggal 4 Juli 2003 telah ditunjuk areal hutan di Provinsi Jawa Barat seluas 816.603 (delapan ratus enam belas ribu enam ratus tiga) hektar sebagai kawasan hutan di antaranya Kawasan Hutan Lindung di Kelompok Hutan Gunung Ciremai Kabupaten Kuningan dan Majalengka. Bahwa Kawasan Hutan Lindung memiliki keanekaragaman hayati yang tinggi seperti berbagai jenis flora dan fauna bahkan 
Nurhalida Yogaswara, Edhi Martono, Djaka Marwasta -- Optimalisasi Peran Rimbawan Muda Dalam Pengelolaan Taman Nasional Gunung Ciremai Dan Implikasinya Terhadap Ketahanan Wilayah

(Studi di Balai Taman Nasional Gunung Ciremai Kuningan, Jawa Barat)

beberapa termasuk langka. Sehubungan hal tersebut maka, untuk menjamin perlindungan, kelestarian dan pemanfaatan potensi kawasan hutan tersebut, sesuai dengan ketentuan Peraturan Pemerintah (PP) Nomor 68 tahun 1998 tentang Kawasan Suaka Alam dan Kawasan Pelestarian Alam, dirubahlah fungsi kawasan Hutan Lindung Gunung Ciremai sebagai kawasan pelestarian alam dengan fungsi Taman Nasional.

Pengelolaan sumberdaya hutan di Indonesia dilakukan oleh para rimbawan dimana diartikan sebagai kelompok yang bekerja bagi dan untuk mengelola sumberdaya hutan. Berbagai profesi yang termasuk kedalam kategori rimbawan meliputi pemikir, akademisi, pengelola, pelaksana serta pelaku industri dan bisnis, bahkan mereka yang bertindak sebagai pengamat hutan dan kehutanan. Peran serta rimbawan dalam perspektif pengelolaan sumberdaya hutan tidak terlepas dari sistem nilai yang dianut serta budaya kerjanya. Menurut Haeruman (2005), budaya kerja yang dimiliki rimbawan diharapkan dapat membentuk etika kerja dalam pembangunan kehutanan yang amat penting. Kaidah dasar budaya yang perlu didukung untuk membentuk etika kerja dalam paradigma pengelolaan hutan lestari seperti memberikan perhatian utama pada tatanilai masyarakat, bangsa dan negara, yang menjadi subjek memberikan perhatian penuh dan lebih besar kepada kepentingan hutan lestari dan masyarakat yang terkait.

Berdasarkan latar belakang yang telah dipaparkan sebelumnya, bahwa pentingnya konservasi lingkungan dengan menguatnya kesadaran masyarakat dan agenda konservasi di tingkat internasional mendorong pemerintah Indonesia untuk menerapkan fungsi kawasan hutan menjadi kawasan konservasi seperti
Taman Nasional. Melihat hal tersebut, dengan dirubahnya fungsi Gunung Ciremai menjadi Taman Nasional maka bagaimana optimalisasi dari pengelolaan Taman Nasional Gunung Ciremai (TNGC) melalui pihakpihak yang berperan langsung dalam hal ini adalah rimbawan khususnya dalam agenda pengembangan dan perwujudan kawasan konservasi di Indonesia.

Berdasarkan pengantar yang telah dipaparkan di atas, tujuan dari penelitian ini adalah mengetahui optimalisasi peran rimbawan muda dalam pengelolaan Taman Nasional Gunung Ciremai dan implikasi optimalisasi peran rimbawan muda dalam pengelolaan Taman Nasional Gunung Ciremai terhadap ketahanan wilayah

Metode yang digunakan dalam penelitian ini adalah metode deskriptif, yaitu metode penelitian untuk membuat gambaran mengenai situasi atau kejadian Metodepenelitian deskriptif bertujuan untuk mendeskripsikan, mencatat, menganalisis, dan menginterpretasikan kondisikondisi yang terjadi pada saat ini Dengan kata lain, mendeskripsikan atau menjelaskan sesuatu hal seperti apa adanya, sehingga memberi gambaran yang jelas tentang situasi-situasi di lapangan apa adanya (Adi, 2008; Milles dan Huberman, 1984).

Lokasi penelitian ini dilakukan di kawasan Taman Nasional Gunung Ciremai yang dipegang oleh Balai Taman Nasional Gunung Ciremai (BTNGC) dimana sebagai unit pelaksana teknis Kementrian Lingkungan Hidup dan Kehutanan semenjak hutan Gunung Ciremai beralih fungsi menjadi kawasan pelestarian alam. Adapun alasan peneliti memilih melakukan penelitian di Balai TNGC karena sesuai dengan sistem pengelolaan Taman Nasional Gunung Ciremai (TNGC) kolaboratif berbasiskan masyarakat. 
Materi yang ditanyakan kepada kelompok rimbawan tradisional terfokus lebih banyak menggali tentang peran rimbawan muda dalam mengoptimalkan pengelolaan Taman Nasional Gunung Ciremai dan yang berkaitan dengan ketahanan wilayah dari upaya pengelolaan TNGC. Seluruh data yang diperoleh diolah dan dianalisis terkait bagaimana optimalisasi peran rimbawan muda dalam melestarikan TNGC. Data tersebut diperoleh dari hasil wawancara terhadap Ketua Balai TNGC, Kepala STPN I Kuningan, dan perwakilan resort di setiap daerah yang berada sekitar TNGC. Selain itu, melalui pengamatan atau observasi yang mana diharapkan dapat memberikan penjelasan gambaran menyeluruh tentang faktor eksternal maupun internal dari pengelolaan TNGC dimana implikasinya terhadap ketahanan wilayah sekitar TNGC (Adi, 2008; Sunardi, 1997).

\section{PEMBAHASAN}

\section{Profil Balai Taman Nasional Gunung Ciremai}

Balai Taman Nasional Gunung Ciremai termasuk unit pelaksana teknis Kementerian Lingkungan Hidup dan Kehutanan yang berdasarkan pada Peraturan Menteri Kehutanan Nomor: P.52/Menhut-II/2009 Tanggal 27 Juli 2009 Tentang Perubahan Kesatu Atas Peraturan Menteri Kehutanan Nomor P.03/Menhut-II/2007 Tentang Organisasi dan Tata Kerja Unit Pelaksana Teknis Taman Nasional termasuk pada Tipe B yang kelembagaannya dipimpin oleh Kepala Balai (eselon III-A) yang bertanggung jawab kepada Direktur Jenderal Konservasi Sumber Daya Alam dan Ekosistem (KSDAE), yang membawahi satu orang Kepala Sub Bagian Tata Usaha dan dua orang Kepala
Seksi (eselon IV-A). (Statistik Balai Taman Nasional Gunung Ciremai Tahun 2015)

\section{Taman Nasional Gunung Ciremai (TNGC) Sejarah dan Kondisi Geografis}

Taman Nasional Gunung Ciremai (TNGC) merupakan Taman Nasional ke-50 di Indonesia yang merupakan Taman Nasional termuda. Penunjukkannya berdasarkan Keputusan Menteri Kehutanan Republik Indonesia Nomor 424/Menhut-II/2004 tanggal 19 Oktober 2004 Tentang Perubahan Fungsi Kawasan Hutan Lindung pada Kelompok Hutan Gunung Ciremai Seluas \pm 15.500 (Lima Belas Ribu Lima Ratus) yang terletak di Kabupaten Kuningan dan Majalengka, Propinsi Jawa Barat menjadi Taman Nasional.

Sebelumnya menjadi kawasan Taman Nasional, ketika zaman pemerintahan Kolonial Belanda, kawasan hutan Gunung Ciremai sudah ditetapkan sebagai kawasan hutan tutupan atau hutan lindung. Ketika pemerintahan Indonesia di Tahun 1978, hutan Gunung Ciremai ditetapkan sebagai hutan produksi yang pengelolaannya diserahkan kepada Perum Perhutani, dimana sebagian besar vegetasi hutan alam diganti menjadi vegetasi dengan tujuan produksi yang mayoritas ditanami pohon pinus. Pengelolaannya pun oleh Perhutani dikembangkan sistem Pengelolaan Hutan Bersama Masyrakata (PHBM) di dalamnya melibatkan masyarakat salah satu programnya adalah kegiatan tumpang sari berupa tanaman sayuran di bawah tegakan hutan pinus (Renstra Balai Taman Nasional Gunung Ciremai 2010-2014)

Untuk mengembalikan fungsi ekologis Gunung Ciremai akibat kegiatan produksi maka pada Tahun 2003 sebagian kelompok hutan produksi yang dikelola oleh Perum Perhutani dialihfungsikan sebagai kawasan 
Nurhalida Yogaswara, Edhi Martono, Djaka Marwasta -- Optimalisasi Peran Rimbawan Muda Dalam Pengelolaan Taman Nasional Gunung Ciremai Dan Implikasinya Terhadap Ketahanan Wilayah

(Studi di Balai Taman Nasional Gunung Ciremai Kuningan, Jawa Barat)

hutan lindung yang dapat memberikan jasa lingkungan dan keanekaragaman hayati. Meskipun demikian, pengelolaan kawasan Gunung Ciremai masih dilakukan oleh Perum Perhutani dan secara prakteknya pengalihan fungsi kawasannya belum ditindaklanjuti dengan pengelolaan kawasan lindung yang baik dan benar. Masyarakat khususnya penggarap masih melakukan kegiatan tumpang sari dan menggarap di kawasan hutan lindung.

Pemerintah Kabupaten Kuningan telah menetapkan kawasan Ciremai sebagai kawasan lindung, konservasi alam, dan zona resapan air melalui Peraturan Daerah Nomor 38 Tahun 2001 tentang Rencana Umum Tata Ruang Gunung Ciremai. Kebijakan-kebijakan pokok tersebut diantaranya meliputi mengembangkan pola pemanfaatan ruang di kawasan Gunung Ciremai sebagai kawasan lindung, konservasi alam dan zona resapan air, meningkatkan fungsi kawasan Gunung Ciremai melalui upaya-upaya konservasi, observasi, penelitian, wisata alam dan kegiatan sejenisnya yang dipandang tidak mengurangi fungsi kawasan hutan saat ini hingga mendatang.

Kawasan hutan Gunung Ciremai merupakan ekosistem yang relatif masih utuh dengan tipe hutan dataran rendah, hutan hujan pegunungan, dan hutan pegunungan yang diantaranya memiliki vegetasi hutan alam primer, memiliki keanekaragaman hayati yang tinggi. Selain itu juga merupakan daerah resapan air bagi kawasan di bawahnya (Kabupaten Kuningan, Kabupaten Majalengka, Kabupaten Cirebon dan Kota Cirebon), memiliki potensi ekowisata yang tinggi serta hasi non kayunya. Hutan di kawasan TNGC sebagian besar merupakan hutan alam primer (virgin forest) yang dikelompokkan ke dalam tiga jenis yaitu hutan hujan dataran rendah (200-1000 mdpl), hutan hujan pegunungan atau zona montana (1000-2400 mdpl), hutan pegunungan sub alpin (>2400 mdpl).

Gunung Ciremai merupakan gunung tertinggi di Jawa Barat dengan pucak tertinggi memiliki ketinggian 3.078 mdpl membentuk kerucut di sisi sebelah Utara sisa Kaldera Geger Halang berukuran 4,5 x 5 km. Kawasan TNGC berada di koordinat $108^{\circ} 21^{\prime} 35^{\prime \prime}$ BT dan 6 50'25" LS 6 58 '26" LS. Secara administratif meliputi dua wilayah kabupaten yaitu sebelah Barat termasuk Kabupaten Majalengka, dan sebelah Timur termasuk Kabupaten Kuningan (Rencana Pengelolaan Kawasan Taman Nasional Gunung Ciremai).

Kawasan TNGC memiliki fungsi sebagai perlindungan sistem penyangga kehidupan dan fungsi hidrologis yang sangat penting sebagai daerah resapan air dan sumber mata air. Di kawasan Timur Ciremai (Kuningan) terdapat 156 sumber mata air yang potensial, sebanyak 147 titik sumber mata air terus menerus sepanjang tahun dengan rata-rata debit air yang cukup besar 50-2000 liter/detik (BAPPEDA Kabupaten Kuningan, 2000). Berdasar hasil inventarisasi sumber mata air di Kawasan Barat Ciremai (Majalengka) terdapat 36 sumber mata air dan 7 sungai. Debit sumber mata air adalah berkisar antara 0,5 s/d 40 liter/ detik dan 50 s/d 200 liter per detik untuk debit sungai (BKSDA Jawa Barat II, 2006).

Kawasan TNGC bertipe iklim B yaitu kering atau setengah kering dan bertipe $\mathrm{C}$ yaitu iklim dengan variasi suhu tahunan yang jelas (Klasifikasi Iklim Schmidt dan Ferguson, 1952). Rata-rata curah hujan 2.000-4.000 $\mathrm{mm} /$ tahun. Temperatur bulanan kawasan Timur Ciremai (Kuningan) berkisar antara 18-22 ${ }^{\circ} \mathrm{C}$ (BAPPEDA Kabupaten Kuningan, 2000), sedangkan kawasan barat Ciremai (Majalengka) kisaran suhu antara $18,8-37,0^{\circ} \mathrm{C}$ dengan tekanan rata-rata udara sebesar 1.010 
mb, dan kelembaban sekitar 633\%-89\%. Curah hujan rata-rata tertinggi mencapai 295,14 mm dan curah hujan rata-rata terendah 48,71 mm (BAPPEDA Majalengka, 2008). Kondisi topografi bervariasi mulai dari landai samapi curam pada umumnya berombak, berbukit, dan bergunung dengan membentuk kerucut di bagian puncak. Kemiringan lahan yang termasuk landai (0-8\%) sebesar 73,48\%.

\section{Kondisi Demografis}

Terdapat 27 desa di 7 kecamatan di Kabupaten Kuningan di sekitar kawasan TNGC sebelah timur. Luas keseluruhan desa tersebut adalah $105,5 \mathrm{~km}^{2}$. Jumlah penduduk dari desa-desa tersebut adalah 64.666 jiwa dengan kepadatan penduduk $612,96 / \mathrm{km}^{2}$ (BPS Kabupaten Kuningan, 2003). Sedangkan Kabupaten Majalengka terdapat 18 desa di 7 Kecamatan sekitar kawasan TNGC sebelah barat Luas keseluruhan desa tersebut adalah $\pm 107,31 \mathrm{~km}^{2}$, dengan jumlah penduduk mencapai 287.439 jiwa (BPS Kabupaten Majalengka, 2005).

Mata pencaharian penduduk yang berada di sekitar kawasan TNGC pada Kabupaten Kuningan yaitu Petani sebanyak 65.476 orang $(68,79 \%)$, Industri sebanyak 2.323 orang $(2,46 \%)$, dan sektor jasa sebanyak 27.097 orang $(28,55 \%)$. Sedangkan pada Kabupaten Majalengka untuk mata pencaharian di sektor pertanian sebanyak (34\%), baik di lahan milik penggarap atau buruh tani, di sektor industri pengolahan sebanyak (33\%), 17\% di sektor perdagangan, dan sisanya tersebar di sektor jasa, angkutan, perkebunan, perikanan, dan perdagangan.

Kawasan TNGC dikelilingi oleh 45 keseluruhan desa yang berada di Kabupaten Kuningan dan Majalengka dengan pertumbuhan penduduk yang tinggi $( \pm 3,34 \%$ per tahun), sehingga meningkatnya kebutuhan air, meningkatnya kebutuhan bahan makanan, keterbatasan lapangan kerja, dan banyaknya pengangguran menyebabkan besarnya tekanan terhadap hutan untuk memenuhi kebutuhan mereka. Interaksi masyarakat dengan kawasan Gunung Ciremai secara ekonomi ditunjukkan dengan ketergantungan masyarakat dalam memanfaatkan hasil hutan. Selain itu, beberapa situs yang terdapat di dalam kawasan Gunung Ciremai merupakan bagian dari kegiatan ritual kepercayaan dan budaya bagi sebagian masyarakat di sekitar dan di luar kawasan Gunung Ciremai.

\section{Rimbawan Muda Taman Nasional Gunung Ciremai (TNGC)}

Rimbawan muda adalah seseorang yang mempunyai pendidikan kehutanan (Rimbawan Tradisional) dan atau berpengalaman yang melakukan langsung kegiatan pengelolaan hutan (Rimbawan Organik), dimana mereka yang memasuki kategori masa remaja awal hingga dewasa awal yaitu 12-16 tahun hingga 26-35 tahun.

Rimbawan dianggap lebih mengetahui hal-hal tentang hutan dituntut untuk dapat menghadapi berbagai tantangan antara lain terkait peningkatan produksi hasil hutan untuk dimanfaatkan bagi kemakmuran bangsa serta dituntut keahliannya dalam dalam mengelola sumber daya hutan agar terjamin kelestarian fungsinya dan terciptanya kualitas lingkungan hidup yang baik. Dengan melakukan usaha-usaha konservasi dan pelestarian sumber-sumber alam dengan jalan menempatkannya sejajar dengan prioritas-prioritas yang bersifat materi dan produksi kayu semata-mata. Seorang rimbawan akan menjadi ujung tombak dalam pengelolaan hutan Indonesia dan jika disimak 
Nurhalida Yogaswara, Edhi Martono, Djaka Marwasta -- Optimalisasi Peran Rimbawan Muda Dalam Pengelolaan Taman Nasional Gunung Ciremai Dan Implikasinya Terhadap Ketahanan Wilayah

(Studi di Balai Taman Nasional Gunung Ciremai Kuningan, Jawa Barat)

sejarah profesi rimbawan ternyata pada saat ini jiwa pengabdian rimbawan semakin diperlukan selain keahliannya. Kehutanan buka pekerjaan white collar, calon forester, tetapi profesi yang lebih banyak berorientasi ke lapangan, yaitu ke hutan (Informasi Teknis Vol. 6 No.2, Balai Besar Penelitian Bioteknologi dan Pemuliaan Tanaman Hutan, 6:2008).

Dalam Deklarasi Cangkuang tahun 1992 dimana sebagai Landasan Darma Bakti Rimbawan Indonesia menyebutkan bahwa dalam pengelolaan hutan pada hakekatnya merupakan aktivitas yang mendudukkan hutan sebagai ekosistem untuk sebesar-besar kesejahteraan dan kebahagiaan manusia lahir dan batin dengan mempertahankan kelestarian fungsi dan manfaatnya. Pelaksanaan pengelolaan tersebut sebagai pengejawantahan dari rasa syukur rimbawan terhadap Tuhan dengan dilakukan berazaskan kerakyatan, keadilan, partisipatif, demokratis, keterbukaan, keterpaduan, kejujuran dan bertanggungjawab. Dalam Kode Etik Rimbawan Indonesia memberikan penjelasan mengenai definisi dari rimbawan yaitu seseorang yang mempunyai pendidikan kehutanan dan atau berpengalaman di bidang kehutanan dan terikat oleh normanorma (Naim, 2011).

Pengelolaan sumberdaya hutan di Indonesia dilakukan oleh para rimbawan yang karena keprofesiannya berhubungan dengan hutan dan kehutanan. Rimbawan diartikan sebagai kelompok profesi yang bekerja bagi dan untuk mengelola sumberdaya hutan. Berbagai profesi yang termasuk ke dalam kategori rimbawan meliputi pemikir, akademisi, pengelola, pelaksana serta pelaku industri dan bisnis, bahkan mereka yang bertindak sebagai pengamat hutan dan kehutanan.
Dalam hal ini, kelompok rimbawan tradisional adalah pihak dari BTNGC yang bekerja sama dalam pengelolaan TNGC dengan rimbawan organik yaitu pemuda dan masyarakat yang tergabung ke dalam kelompok penggerak pariwisata (KOMPEPAR). Pengelolaan kawasan TNGC mengacu pada kebijakan nasional dan regional sektor kehutanan, kebijakan nasional dan regional bidang perlindungan hutan dan konservasi alam, kebijakan pengembangan wilayah, kebijakan pengembangan pariwisata, kebijakan pengelolaan taman nasional, dan tujuan pengelolaan Taman Nasional serta sistem pengelolaan hutan yang dikembangkan daerah secara kolaboratif berbasis masyarakat.

\section{Kebijakan Kehutanan Nasional dan Pemerintah Jawa Barat}

Berdasarkan Undang-undang Nomor 5 Tahun 1990, Taman Nasional didefinisikan sebagai kawasan pelestarian alam yang mempunyai ekosistem asli, dikelola dengan sistem zonasi yang dimanfaatkan untuk tujuan penelitian, ilmu pengetahuan, pendidikan, emnunjang budidaya, pariwisata dan rekreasi alam. Fungsinya diarahkan terhadap perlindungan terhadap ekosistem penyangga kehiduapan, pengawetan sumber plasma nutfah dan ekosistemnya dan pelestarian pemanfaatan.

Berdasarkan SK Menhut Nomor 456/ Menhut-II/2004 ditetapkan 5 (lima) kebijakan prioritas pembangunan kehutanan 20052009, yaitu (1) Pemberantasan pencurian kayu di hutan negara dan perdagangan kayu illegal, (2) Revitalisasi sektor kehutanan khususnya industri kehutanan, (3) Rehabilitasi dan konservasi sumberdaya hutan, (4) Pemberdayaan ekonomi masyarakat di 
dalam dan sekitar kawasan, (5) Pemantapan kawasan hutan

Kebijakan Prioritas Perlindungan Hutan dan Konservasi Alam (PHKA) dalam visinya yaitu terwujudnya konservasi sumberdaya alam hutan dan ekosistemnya yang aman dan mantap secara legal formal, didukung kelembagaan yang kuat dalam pengelolaannya serta mampu memberikan manfaat optimal kepada masyarakat melalui beberapa misi, yaitu (1) Memantapkan pengelolaan sumberdaya alam hayati dan ekosistemnya. (2) Memantapkan perlindungan hutan dan penegakkan hukum (law enforcement). (3) Mengembangjan secara optimal pemanfaatan sumberdaya alam hayati dan ekosistemnya berdasarkan prinsip kelestarian. (4) Mengembangkan kelembagaan dan kemitraan dalam rangka pengelolaan, perlindungan dan pemanfaatan sumberdaya alam hayati dan ekosistemnya.

Kebijakan Pemerintah Provinsi Jawa Barat berdasarkan Perda Provinsi Jawa Barat Nomor 6 Tahun 2003 Tentang Rencana Tata Ruang Wilayah Provinsi Jawa Barat, adalah (1) Kebijakan pola tata ruang kawasan lindung, yaitu meningkatkan luas kawasan yang berfungsi lindung dan menjaga kualitas lindung. (2) Kebijakan pola tata ruang kawasan budidaya, yaitu mempertahankan lahan sawah (beririgasi). (3) Kebijakan daya dukung dan daya tampung lingkungan hidup, yaitu meningkatkan daya dukung lingkungan alamiah dari buatan serta menjaga keseimbangan data tampung lingkungan untuk menjaga proses pembangunan yang bekelanjutan.

\section{Kebijakan Pemerintah Kabupaten Kuningan dan Majalengka}

Berdasarkan Peraturan Daerah Pemerintah Kabupaten Kuningan Nomor 38 Tahun 2002 tentang Rencana Umum Tata
Ruang Gunung Ciremai bahwa Pemerintah Kabupaten Kuningan telah menetapkan kawasan Gunung Ciremai sebagai kawasan lindung, konservasi alam, dan zona resapan air. Kebijakan tersebut adalah (1) Mengembangkan pola pemanfaatan ruang di kawasan Gunung Ciremai sebagai kawasan lindung, konservasi alam dan zona resapan air. (2) Meningkatkan tingkatnya fungsi kawasan Gunung Ciremai sebagai kawasan lindung, konsrvasi alam, zona resapa air melalui upayaupaya konservasi, observasi, penelitian, wisata alam dan kegiatan sejenisnya yang tidak merusak fungsi kawasan.

Pendeklarasian Kabupaten Kuningan sebagai Kabupaten Konservasi Pada Tanggal 2 Februari Tahun 2006 didasari karakteristik wilayah dalam mewujudkan pembangunan yang berkelanjutan melalui perlindungan sistem penyangga kehidupan dan pengawetan keanekaragaman hayati. Salah satu kebijakan yang sedang dilaksanakan adalah perubahan fungsi kawasan hutan Gunung Ciremai menjadi Taman Nasional.

Kebijakan Rencana Tata Ruang Wilayah (RTRW) Kabupaten Majalengka Tahun 200520015 terkait rencana detail ruang kawasan Gunung Ciremai termasuk arahan kebijakan makro atas RTRW Majalengka. Kabupaten Majalengka secara garis besar terbagi menjadi tiga wilayah pengembangan (WP), WP Utara, WP Tengah, dan WP Selatan. WP tersebut diarahkan sebagai pusat layanan sosial dan umum, pengembangaan pertanian, pengembangan, kawasan perkotaan, pengembangan pariwisata dan terminal regional.

\section{Pengelolaan Kawasan Taman Nasional Gunung Ciremai (TNGC) \\ Berdasarkan Undang-undang Nomor 5 Tahun 1990, Taman Nasional (TN)}


Nurhalida Yogaswara, Edhi Martono, Djaka Marwasta -- Optimalisasi Peran Rimbawan Muda Dalam Pengelolaan Taman Nasional Gunung Ciremai Dan Implikasinya Terhadap Ketahanan Wilayah

(Studi di Balai Taman Nasional Gunung Ciremai Kuningan, Jawa Barat)

didefinisikan sebagai kawasan pelestarian alam yang mempunyai ekosistem asli, dikelola dengan sistem zonasi yang dimanfaatkan untuk tujuan penelitian, ilmu pengetahuan, pendidikan, menunjang budidaya, pariwisata dan rekreasi alam. Sesuai dengan kondisi umum kawasan, kebijakan pengelolaan, landasan hukum, serta pengalaman empiris maka sistem pengelolaan Taman Nasional Gunung Ciremai (TNGC) kolaboratif berbasiskan masyarakat. Dengan visinya yaitu "Terwujudnya kelestarian ekosistem Taman Nasional Gunung Ciremai yang dapat memberikan manfaat optimal kepada masyarakat secara berkelanjutan".

Untuk mewujudkan visi tersebut, maka misi pengelolaan TNGC adalah memantapkan pengelolaan konservasi sumber daya alam hayati dan ekosistem TNGC sebagai kawasan konservasi, perlindungan dan pengaturan tata air, sistem pengelolaan yang berbasiskan masyarakat, meningkatkan kebersamaan, kemitraan, dan sinergitas para pihak, meningkatkan kapasitas sumber daya manusia dan mengembangkan kearifan masyarakat dalam sistem pengelolaan TNGC kolaboratif, mengoptimalkan fungsi dan manfaat TNGC berdasarkan prinsip kelestarian, keadilan dan kebersamaan, dan mengembangkan sistem informasi dan promosi (Rencana Pengelolaan Kawasan TNGC 2006-2025 Balai Konservasi Sumber Daya Alam Jawa Barat II).

Integrasi dan koordinasi mempunyai peranan penting dalam upaya seluruh tahapan kegiatan pengelolaan TNGC dimaksudkan agar semua pihak yang terkait memiliki sense of belonging terhadap kawasan. Dengan meningkatknya kepedulian dan mendorong terwujudnya keberhasilan pencapaian kelestarian pengelolaan taman nasional. Pengembangan sistem promosi yang dilakukan bersama-sama dengan organisasi pemerintah dan non pemerintah baik dari dalam dan luar negeri dan masyarakat. Upaya tersebut dilakukan agar masyarakat luas dapat mengetahui potensi dan permasalahan yang ada di kawasan TNGC, sehingga dapat memberikan kontribusi bagi pengembangan kawasan TNGC secara optimal.

Upaya menjalin kerjasama (Collaborative management) dengan berbagai pihak dilakukan agar memperkuat kelembagaan pengelolaan taman nasional. Hal tersebut dapat memacu partisipasi semua pihak dalam kegiatan pengelolaan kawasan TNGC secara terpadu. Dengan memberikan pemahaman kepada masyarakat luas bahwa sistem pengelolaan kawasan TNGC memerlukan kerjasama berbagai pihak. Hal ini menunjukkan bahwa tanggung jawab pengelolaan kawasan TNGC tidak semata tanggung jawab dari pengelola TNGC (Rencana Pengelolaan Kawasan TNGC 2006-2025 Balai Konservasi Sumber Daya Alam Jawa Barat II).

Dalam hal ini pembinaan daerah penyangga dititikberatkan pada upaya peningkatan hubungan antara masyarakat dan kawasn TNGC sehingga kawasan TNGC dirasakan manfaatnya. Sebagai salah satu bentuk integrasi dan koordinasi antara pengelola dan masyarakat bentuk kegiatannya adalah peningkatan interaksi melalui penyuluhan dan pelatihan serta kegiatan lain dan penciptaan sumber-sumber mata pencaharian alternatif khususnya bagi masyarakat yang sebelumnya adalah penggarap. Berdasarkan hal tersebut, maka masyarakat yang di dalamnya terdapat beberapa pemuda dimana dulunya adalah penggarap yang berada dan berbatasan langsung dengan kawasan TNGC berinisiatif untuk membentuk kelompok pengelola pariwisata. 
Melalui Nota Perjanjian Kemitraan antara Balai Taman Nasional Gunung Ciremai (BTNGC) tentang pengelolaan kawasan untuk tujuan pariwisata sesuai dengan potensi yang ada dan karakteristik wilayah masing-masing. Dengan catatan pengelolaan tersebut hanya dalam zona pemanfaatan serta harus terjamin kelestarian keanekaragaman hayati dan ekosistem di kawasan TNGC.

Hal tersebut pun berdasarkan Peraturan Pemerintah Nomor 18 Tahun 1994 tentang Pengusahaan Pariwisata Alam di Zona Pemanfataan Taman Nasional salah satunya bahwa pengelola dapat melakukan pengelolaan secara bersama-sama dengan pihak lain untuk mengelola kawasan wisata alam di lokasi pengelolaan. Dengan dibentuknya kelompok pengelola pariwisata diharapkan kegiatan yang ada di dalamnya menunjang dalam pengelolaan hutan dan menjaga kelestarian hutan yang berprinsip pada optimalisasi fungsi dan manfaat kawasan hutan dengan tetap memperhatikan aspek ekologi, ekonomi dan sosial budaya.

\section{Peran Rimbawan Muda}

Rimbawan muda adalah seseorang yang mempunyai pendidikan kehutanan (Rimbawan Tradisional) dan atau berpengalaman yang melakukan langsung kegiatan pengelolaan hutan (Rimbawan Organik), dimana mereka yang memasuki kategori masa remaja awal hingga dewasa awal yaitu 12-16 tahun hingga 26-35 tahun. Rimbawan akan menjadi ujung tombak dalam pengelolaan hutan Indonesia dan jika disimak sejarah profesi rimbawan ternyata pada saat ini jiwa pengabdian rimbawan semakin diperlukan selain keahliannya. Kehutanan buka pekerjaan white collar, calon forester, tetapi profesi yang lebih banyak berorientasi ke lapangan, yaitu ke hutan (Informasi Teknis Vol. 6 No.2, Balai Besar Penelitian Bioteknologi dan Pemuliaan Tanaman Hutan, 6:2008)

Dalam hal ini, kelompok rimbawan tradisional adalah pihak dari BTNGC yang bekerja sama dalam pengelolaan TNGC dengan rimbawan organik yaitu pemuda dan masyarakat yang tergabung ke dalam kelompok penggerak pariwisata (KOMPEPAR). Upaya menjalin kerjasama (Collaborative management) dengan berbagai pihak dilakukan agar memperkuat kelembagaan pengelolaan Taman Nasional. Hal tersebut dapat memacu partisipasi semua pihak dalam kegiatan pengelolaan kawasan TNGC secara terpadu. Dengan memberikan pemahaman kepada masyarakat luas bahwa sistem pengelolaan kawasan TNGC memerlukan kerjasama berbagai pihak. Hal ini menunjukkan bahwa tanggung jawab pengelolaan kawasan TNGC tidak semata tanggung jawab dari pengelola TNGC (Rencana Pengelolaan Kawasan TNGC 2006-2025 Balai Konservasi Sumber Daya Alam Jawa Barat II).

Kelompok masyarakat sebagai mitra TNGC sebagai inisiator pengelola pariwisata alam sesuai potensi daerah masing-masing dan dari BTNGC sebagai fasilitator serta melakukan pendampingan. Karena dengan adanya integrasi dan koordinasi atas peran dari BTNGC dengan Kelompok Pemuda dan Masyarakat Mitra TNGC sangat mempengaruhi terhadap terwujudnya kelestarian ekosistem TNGC berbasiskan konservasi sekaligus dapat memberikan manfaat kepada masyarakat. Bentuk upaya dalam pengelolaan kolaborasi sebagai realisasi dari Permenhut untuk membuka ruang pendekatan pengelolaan secara kolaboratif yaitu dengan kerjasama Kelompok Pemuda Masyarakat Pengelola Pariwisata Alam Mitra TNGC. Begitu pula 
Nurhalida Yogaswara, Edhi Martono, Djaka Marwasta -- Optimalisasi Peran Rimbawan Muda Dalam Pengelolaan Taman Nasional Gunung Ciremai Dan Implikasinya Terhadap Ketahanan Wilayah

(Studi di Balai Taman Nasional Gunung Ciremai Kuningan, Jawa Barat)

dalam menjalankan realisasi sesuai dengan kebijakan masing-masing daerah yang berbatasan dengan TNGC bahwa dalam segala kegiatan pengembangan wilayah pengelolaan pariwisata alam tersebut haruslah berbasis konservasi lingkungan yang berkelanjutan. Bentuk optimalisasi pemanfaatan Sumber Daya Hutan TNGC yaitu melalui pemanfaatan jasa lingkungan dan wisata alam, pengembangan potensi keanekaragaman hayati, membangun mekanisme pemanfaatan jasa lingkungan dan wisata alam.

Hal tersebut bertujuan untuk mempertahankan fungsi hutan sebagai sumber daya pembangunan dan penyangga sistem kehidupan secara lestari dan efisien dengan meningkatnya pendayagunaan dan pemeliharaan sumber daya alam beserta ekosistem juga terpeliharanya kelestarian dari lingkungan hidup.

\section{Kendala-kendala Yang Dihadapi}

Berdasarkan temuan lapangan dan kajian literatur dalam penelitian ini, kendala yang terjadi optimalisasi peran rimbawan muda adalam pengelolaan TNGC dan implikasinya terhadap ketahanan wilayah di antaranya, kurangnya inovasi sehingga diperlukannya sebuah terobosan untuk menarik wisatawan lebih banyak dari berbagai kalangan atau luar kota agar nilai pemasukan bagi kelompok penggerak pariwisata maupun desa setempat menjadi meningkat. Karena sejak alih profesi sebelumnya sebagai petani penggarap kemudian sekarang menjadi pengelola pariwisata alam nilai pemasukannya tidak menentu.

Sarana dan prasarana yang masih dirasa kurang untuk menunjang pengembangan pengelolaan pariwisata alam, di antaranya karena kurangnya sokongan dana sehingga terdapat beberapa yang menggunakan dana swadaya dari masyarakat yang tidak dapat sepenuhnya mencukupi. Dalam hal pemanfaatan selain pariwisata alam seperti kegiatan pengembangan atau inovasi hasil perkebunan atau pertanian masyarakat sekitar berupa produk hanya di daerah tertentu saja dan masih kurang optimal karena mahalnya biaya produksi.

Kurang optimalnya pelaksanaan terkait pembinaan dan inventarisasi varietas kekayaan TNGC untuk membentuk sumber daya manusia dari masyarakat sekitar kawasan sebagai seorang interpreter masih sangat sedikit. Penyebaran informasi terkait zonasi TNGC kurang optimal sehingga beberapa masyarakat masih belum paham apa itu sistem zonasi TNGC. Beberapa masyarakat masih menggantungkan mata pencahariannya dari hasil sumber daya alam yang ada di kawasan TNGC, sehingga terdapat beberapa pelanggaran seperti mencuri burung dan sebagainya.

Belum optimalnya kualitas pemuda dan masyarakat yang tergabung ke dalam kelompok penggerak pariwisata yang mana sebelumnya adalah petani penggarap, sehingga perlu dibina lagi atas alih profesi tersebut yang kini adalah pengelola pariwisata alam dengan berbasiskan konservasi. Kurangnya atau tidak menentunya pendapatan yang diperoleh dari mengelola pariwisata alam sehingga timbulnya beberapa konflik kepentingan dalam pengelolaan pariwisata alam kawasan TNGC.

Kegiatan pemberdayaan berbasis konservasi seperti bina cinta alam yang mengkaderisasi pelajar dan pemuda khususnya untuk sdar konservasi masih belum optimal yang disebabkan oleh beberapa kendala. Sulitnya regenerasi anggota kelompok yang 
mengelola kawasan TNGC khususnya pemuda karena mereka merasa pendapatan yang diperoleh tidak mencukupi kebutuhan seharihari sehingga mereka memilih untuk bekerja di luar kawasan atau luar kota besar.

\section{Optimalisasi Peran Rimbawan Muda}

Dalam pengelolaan kawasan pelestarian alam tidak terbatas pada satu pihak saja yang memiliki kepentingan tertentu. Adanya saling keteterkaitan di antaranya Balai Taman Nasional Gunung Ciremai (BTNGC) sebagai pelaksana teknis Taman Nasional Gunung Ciremai (TNGC) yang bertanggung jawab kepada Direktur Jenderal Konservasi Sumber Daya Alam dan Ekosistem (KSDAE) dan Kelompok pemuda dan masyarakat yang sudah lama bertempat tinggal dan menggantungkan kehidupannya pada kawasan TNGC. Melalui upaya menjalin kerjasama (collaborative management) oleh BTNGC terhadap kelompok pemuda dan masyarakat sekitar kawasan sebagai bentuk terwujudnya fungsi dan manfaat TNGC dengan prinsip kelestarian dan berbasikan masyarakat. Dijelaskan dalam peraturan kehutanan untuk membuka ruang pendekatan pengelolaan secara kolaboratif yang tertuang dalam Pasal 4 Permenhut P-19/Tahun 2004:

"Kolaborasi dalam rangka pengelolaan Kawasan Suaka Alam dan Kawasan Pelestarian Alam adalah proses kerjasama yang dilakukan oleh para pihak yang bersepakat atas dasar prinsip-prinsip saling menghormati, saling menghargai, saling percaya dan saling memberikan kemanfaatan."

Sesuai dalam penjelasan pasal tersebut bahwa para pihak tersebut di antaranya kelompok masyarakat dalam hal ini sebagai mitra TNGC sebagai inisiator pengelola pariwisata alam sesuai potensi daerah masing- masing dan dari BTNGC sebagai fasilitator serta melakukan pendampingan. Karena dengan adanya integrasi dan koordinasi atas peran dari BTNGC dengan Kelompok Pemuda dan Masyarakat Mitra TNGC sangat mempengaruhi terhadap terwujudnya kelestarian ekosistem TNGC berbasiskan konservasi sekaligus dapat memberikan manfaat kepada masyarakat. Melihat fungsi dari konservasi atas pengelolaan Taman Nasional adalah perlindungan, pengawetan serta pelestarian pemanfaatan. Taman Nasional dapat dikembangkan sebagai kawasan yang mempunyai nilai ekonomis dengan melakukan jasa lingkungan dan pengembangan potensi wisata alam. Sebagai salah satu kawasan pelestarian alam, TNGC memiliki salah satu tujuan pengelolaan berupa pemanfaatan sumberdaya alam hayati dan ekosistemnya secara berkelanjutan.

Dikaitkan dengan kebijakan masingmasing daerah yang berbatasan dengan kawasan TNGC yaitu Kuningan dan Majalengka. Masing-masing daerah memang menyatakan bahwa penataan ruang dan pengembangan daerahnya harus sejalan dengan konservasi. Seperti dalam Kebijakan Penataan Ruang Wilayah Kabupaten Kuningan menyatakan pengembangan kawasan pariwisata berbasis potensi alam dan karakteristik lokal, pemanfaatan sumberdaya harus secara berkelanjutan, pengoptimalan pemanfaatan kawasan budidaya serta sebagai peningkat fungsi kawasan untuk pertahanan dan keamanan (Pasal 5 Peraturan Daerah Kabupaten Kuningan Nomor 26 Tahun 2011 Tentang Rencana Tata Ruang Wilayah Kabupaten Kuningan Tahun 2011-2031).

Begitu pula dengan kebijakan di Kabupaten Majalengka dilihat dari sisi konservasi lingkungan terlebih terkait isu 
Nurhalida Yogaswara, Edhi Martono, Djaka Marwasta -- Optimalisasi Peran Rimbawan Muda Dalam Pengelolaan Taman Nasional Gunung Ciremai Dan Implikasinya Terhadap Ketahanan Wilayah

(Studi di Balai Taman Nasional Gunung Ciremai Kuningan, Jawa Barat)

global warming yang sangat memberikan pengaruh besar terhadap kebijakan penataan ruang dan pengembangan wilayah Majalengka bahwa segala kegiatan pembangunan harus dalam koridor daya dukung lingkungan, sehingga keseimbangan alokasi ruang antara kawasan budidaya dan hutan lindung merupakan prasyarat yang dibutuhkan (Peraturan Daerah Kabupaten Majalengka Nomor 11 Tahun 2011 tentang Rencana Tata Ruang Wilayah Kabupaten Majalengka Tahun 2011-2031).

Bentuk upaya dalam pengelolaan kolaborasi sebagai realisasi dari Permenhut untuk membuka ruang pendekatan pengelolaan secara kolaboratif yaitu dengan kerjasama Kelompok Pemuda Masyarakat Pengelola Pariwisata Alam Mitra TNGC. Begitu pula dalam menjalankan realisasi sesuai dengan kebijakan masing-masing daerah yang berbatasan dengan TNGC bahwa dalam segala kegiatan pengembangan wilayah pengelolaan pariwisata alam tersebut haruslah berbasis konservasi lingkungan yang berkelanjutan. Bentuk optimalisasi pemanfaatan Sumber Daya Hutan TNGC yaitu melalui pemanfaatan jasa lingkungan dan wisata alam, pengembangan potensi keanekaragaman hayati, membangun mekanisme pemanfaatan jasa lingkungan dan wisata alam.

Hal tersebut bertujuan untuk mempertahankan fungsi hutan sebagai sumber daya pembangunan dan penyangga sistem kehidupan secara lestari dan efisien dengan meningkatnya pendayagunaan dan pemeliharaan sumber daya alam beserta ekosistem juga terpeliharanya kelestarian dari lingkungan hidup. Dari sebagian besar yang bersifat teknis di atas harus didukung komitmen dan kesepahaman para pihak yang bersifat politis startegis. Termasuk di dalamnya komitmen dari Pemerintah Pusat maupun daerah serta keseluruhan aspek yang akan mendorong terciptanya suatu keadaan yang kondusif di sektor kehutanan yang pada akhirnya akan mewujudkan kebangkitan kehutanan nasional.

Setelah ditetapkannya status hutan Gunung Ciremai menjadi Taman Nasional sebagaimana pula sebagai salah satu upaya mengembalikan fungsinya. Manfaatnya pun dapat mulai dirasakan melalui kegiatan pendukung terwujudnya tujuan dari TNGC seperti penggunaan lahan dilakukan dengan menetapkan cara yang tepat. Tidak lagi untuk digarap melainkan melalui pemanfaatan lahan sebagai area wisata alam dengan tetap memperhatikan kelestariannya. Yang difokuskan pada optimasi fungsi ekologi dan pemeliharaan kesejahteraan masyarakat sekitar kawasan melalui sistem kolaborasi antara Balai Taman Nasional Gunung Ciremai (BTNGC) dengan masyarakat sekitar kawasan.

\section{Implikasinya Terhadap Ketahanan Wilayah}

Ketahanan wilayah merupakan unsur mandiri penunjang ketahanan nasional. Maka orientasi pembangunan haruslah ditujukan pada pembangunan wilayah. Ketahanan wilayah sebagai satu vektor sebagai unsure ketangguhan dalam ketahanan nasional maka diumpamakan sebagai unsur keuletan di dalamnya (Sunardi, 2004). Adanya vektor ketahanan wilayah maka diperlukan satu model yang dapat menerangkan terbentuknya ketergantungan serta keterkaitan setiap vektor sehingga menghasilkan resultan vektor ketahanan nasional. Dengan diwujudkan oleh pembangunan nasional di dalam wilayah, adanya interaksi vektor ketahanan wilayah di antaranya interaksi sosial, politik, ekonomi, dan pertahanan keamanan (Sunardi, 2004). 
Untuk mengembalikan fungsi ekologi dari hutan Gunung Ciremai maka dirubahlah fungsi hutan gunung ciremai yang tadinya sebagai hutan produksi menjadi kawasan konservasi Taman Nasional berdasarkan Surat Keputusan Menteri Kehutanan No. 424/Menhut-II/2004 tanggal 19 Oktober 2004 tentang Perubahan Fungsi Kelompok Hutan Lindung Pada Kelompok Hutan Gunung Ciremai seluas +15.500 hektar yang terletak di Kabupaten Kuningan dan Majalengka, Propinsi Jawa Barat menjadi Taman Nasional. Dalam penataan ruang tingkat pusat, berdasarkan Undang-undang Nomor 5 tahun 1990 tentang Konservasi Sumberdaya Alam Hayati dan Ekosistemnya, pengelolaan Taman Nasional dapat diatur melalui pola pengaturan ruang dengan sistem zonasi taman nasional.

Ketika hutan kawasan Gunung Ciremai ditetapkan sebagai hutan produksi yang pengelolaannya diserahkan kepada Perum Perhutani. Perubahan fungsi kawasan dari hutan lindung menjadi hutan produksi tapaknya membawa dampak nyata terhadap perubahan ekologi kawasan Gunung Ciremai dimana sebagian besar vegetasi hutan alam diganti menjadi vegetasi dengan tujuan produksi yang mayoritas ditanami pohon pinus. Pengelolaan kawasan yang difungsikan sebagai hutan produksi melalui sistem Pengelolaan Hutan Bersama Masyarakat (PHBM) dengan beberapa program melibatkan masyarakat yang diberi kewenangan untuk turut mengelola dan dapat mengolah lahan berupa tanaman sayuran atau perkebunan di sela-sela tegakan pohon pinus yang disebut kegiatan tumpang sari.

Di antara pihak-pihak yang memiliki peran penting dalam pengelolaan kawasan TNGC haruslah berprinsip pada optimalisasi fungsi dan manfaat kawasan hutan dengan memperhatikan aspek ekologi, ekonomi dan sosial budaya masyarakat. Sekaligus untuk menjawab rumusan masalah kedua penelitian ini yakni implikasi pengelolaan Taman Nasional Gunung Ciremai terhadap Ketahanan Wilayah menggunakan teori Sunardi dimana ketahanan wilayah merupakan unsur mandiri penunjang ketahanan nasional, maka orientasi pembangunan haruslah ditujukan pada pembangunan wilayah dalam hal ini wilayah Kawasan TNGC dan wilayah desa sekitar kawasan serta sejalan dengan penataan zonasi taman nasional. Realisasi pengelolaan TNGC agar hijau dan lestari dengan memperhatikan kajian dari aspek-aspek ekologis, ideologi, politik, ekonomi, sosial budaya, pertahanan dan keamanan.

Adapun beberapa uraian faktor dari masing-masing aspek tolok ukur yang mempengaruhi tingkatan tercapainya indikator pengelolaan kawasan TNGC dapat dilihat dalam penjelasan di bawah ini.

Pertama, aspek ekologi. (1) Dugaan ketidakseimbangan populasi dengan habitat sehinggamenyebabkan satwayang berada dalam kawasan TNGC memasuki lahan pertanian masyarakat di luar kawasan. Kemungkinan disebabkan oleh adanya perubahan perilaku karena sebelumnya di dalam kawasan TNGC ditanami oleh tanaman pertanian namun sekarang sudah tidak diperbolehkan lagi untuk menggarap lahan atau pelaksanaan kegiatan tumpang sari. (2) Minimnya kegiatan pengelolaan keanekaragaman hayati melalui pengembangan lebih lanjut terkait pemanfaatan yang dapat dikembangkan di luar kawasan konservasi TNGC seperti budidaya endemik ataupun budidaya tanaman obat yang dapat digunakan untuk meningkatkan perekonomian masyarakat. (3) Terkait kegiatan rehabilitasi hutan dan lahan kawasan TNGC 
Nurhalida Yogaswara, Edhi Martono, Djaka Marwasta -- Optimalisasi Peran Rimbawan Muda Dalam Pengelolaan Taman Nasional Gunung Ciremai Dan Implikasinya Terhadap Ketahanan Wilayah

(Studi di Balai Taman Nasional Gunung Ciremai Kuningan, Jawa Barat)

pelaksanaannya beberapa masih berdasarkan pada proyek dan belum optimalnya keterlanjutan pemeliharaan setelahnya. (4) Kegiatan inventarisasi dan identifikai serta survey eksploratif atas pengumpulan, pengelolaan data-data ekologi dari vegetasi serta satwa dalam belum sepenuhnya optimal. Hal tersebut berpengaruh ketika menghadapi isu-isu ekologis yang terjadi sehingga masih terdapat kesalahan pengertian dikarenakan pengetahuan yang masih kurang memadai, kendala pada dukungan dana serta komitmen dari pihak terkait.

Kedua, aspek ideologi. Dalam pengelolaan TNGC selayaknya merupakan proses pembangunan nasional yang pelaksanaannya didasarkan atas landasan ideal yaitu Pancasila. Namun, aktualisasi nilai-nilai yang ada dalam Pancasila termasuk nasionalisme dalam pengelolaan sumberdaya hutan TNGC masih kurang, di antaranta masih rendahnya akses masyarakat dalam perumusan kebijakan dalam pembangunan kehutanan, kurangnya partisipasi pemuda khususnya dalam pengelolaan bahkan kelestarian hutannya. Kondisi tersebut tentu tidak dapat mendukung upaya untuk terus memupuk wawasan kebangsaan masyarakat.

Ketiga, aspek politik. Pengelolaan hutan yang berwawasan ketahanan nasional dapat memberikan akses kepada masyarakat, dimana dalam pengelolaann TNGC tercapainya social equity. Tolak ukurnya bahwa kehidupan mereka tidak terganggu dan meningkat kesejahteraannya. Dari segi lain, politik kehutanan juga tidak banyak memberikan perhatian terhadap people interest, sehingga kurang menggugah peran serta masyarakat di sekitar kawasan TNGC khususnya pemuda

Keempat, aspek ekonomi. (1) Tidak menentunya pendapatan masyarakat dengan hanya mengandalkan pengelolaan pariwisata alam kawasan TNGC. Diperlukannya pengembangan, penguatan, pelatihan baik dari potensi-potensi yang masih belum tersentuh hingga kualitas dari sumber daya manusaia yang mendukung jalannya pengelolaan jasa lingkungan dan wisata alam. (2) Perlunya dukungan swadaya dari pihak terkait yang tidak sepenuhnya tercukupi menggunakan swadaya dari masyarakat sendiri dalam mengembangkan sarana dan prasarana wisata alam dan jasa lingkungan yang perlu ditingkatkan. (3) Masih terdapat kemungkinan ketergantungan masyarakat khususnya eks petani penggarap atas hasil dari hutan gunung ciremai kembali meningkat karena kurang menguatnya budaya alih profesi dalam bidang kepariwisataan, sehingga dapat merugikan baik dari sisi Taman Nasionalnya sendiri yang tidak akan lestari tanpa pemeliharaan dan pelestarian. Begitu pula dari sisi sumber daya manusianya tidak dapat mengembangkan keterampilannya di bidang kepariwisataan yang tujuannya sekaligus membuat TNGC yang tetap hijau dan lestari.

Kelima, aspek sosial dan budaya. (1) Sebagian besar program dan proyek yang mengandalkan partisipasi masyarakat hanya sebatas mobilisasi masa yaitu berakhirnya pertisipasi masyarakat setelah proyek sudah berakhir, bukan partisipasi secara aktif walaupon proyek sudah berakhir ada tindakan lanjutan jangka panjang. (2) Masih terdapat kesenjangan antara aturan dengan masyarakat terkait hal pengelolaan kawasan TNGC. (3) Kurangnya saran dan prasarana pendukung dalam peningkatan kapasitas SDM masyarakat. (4) Kurangnya penyelenggaraan pelatihan SDM untuk pengelola kawasan TNGC. (5) Keterbatasan kapasitas fasilitator dan pendamping masyarakat dalam menggali 
potensi yang dapat dikembangkan di tingkat masyarakat. (6) Perlunya peningkatan kapasitas pengetahuan dan keterampilan SDM sekitar kawasan TNGC melalui pelatihan personal guna menunjang pengembangan pengelolaan wisata dan jasa lingkungan yang dilaksanakan oleh pemuda dan masyarakat. (7) Kepedulian masyarakat dalam memelihara budaya peninggalan sejarah tidak disertai dengan dukungan dengan fasilitas sarana dan prasarana pendukung pemeliharaannya.

Keenam, aspek pertahanan dan keamanan. Keberadaan hutan dalam hal ini hutan Gunung Ciremai sebagai bagian dari strategi pertahanan dan keamanan, dimana semua komunitas pohon dalam hutan dengan segala karakter fisik ekologisnya. Secara fisik komunitas pohon menjadi ruang perlindungan, bahkan menjadi benteng pertahanan, sumberdaya hutan juga merupakan sumber logistik wilayah bagi pemenuhan pertahanan dan keamanan. Namun, belum sepenuhnya terkelola dengan baik seperti pemnfaatan tanaman obat dan untuk akses air.

\section{Kondisi Wilayah Sekitar Kawasan TNGC dan Wilayah Konservasi TNGC}

Beralihnya fungsi hutan Gunung Ciremai yang sebelumnya adalah hutan produksi kini menjadi Taman Nasional, tentunya didukung oleh penerimaan masyaraka serta menyadari pentingnnya keberadaan kawasan konservasi TNGC. Masih menemui beberapa hambatan di antaranya sebagian masyarakat memang sudah meninggalkan lahan garapannya di dalam kawasan TNGC, namun terdapat berbagai keinginan lain yang belum sepenuhnya terpenuhi. Seperti alternatif kegiatan mata pencaharian selain menggarap lahan kawasan yaitu dengan beralih fungsi profesi menjadi pengelola wisata alam tetapi dirasa pemasukan mereka tidak menentuu jika dibandingkan masih menggarap.

Dengan kondisi sosial ekonomi masyarakat sekitar TNGC yang masih memiliki ketergantungan terhadap lahan pertanian karena sebelumnya adalah petani penggarap memungkinkan adanya kegiatan pemanfaatan sumber daya alam TNGC yang tidak sesuai dengan kaidah konservasi alam seperti perburuan satwa atau hal-hal yang membuat kebakaran hutan. Program pemberdayaan masyarakat belum cukup optimal karena dengan kapasitas SDM masyarakat yang belum sepenuhnya berdaya dan mandiri dengan pengetahuan serta keterampilannya khususnya di bidang konservasi.

TNGC sebagai kawasan pelestarian alam memiliki banyak potensi yang dapat mendukung efektivitas pengelolaan taman nasional. Dalam pelaksanaan pengelolaannya masih belum begitu optimal dimana masyarakat belum sepenuhnya memahami dan mengenali potensi sumber daya alamnya masih kurang optimalnya semacam pelatihan atau kaderisasi untuk meningkatkan pengetahuan dan keterampilan masyarakat di bidang konservasi. Dalam pendekatan restorasi ekosistem hutan, masyarakat disertakan untuk mengidentifikasi dan menetapkan secara tepat praktek-praktek penggunaan lahan yang akan membantu pemulihan fungsi hutan secara keseluruhan.

Dalam hal ini difokuskan pada optimasi fungsi ekologi dan pemeliharaan kesejahteraan masyarakat sekitarnya. Tujuan dari pendekatan ini adalah memperkuat hubungan antara pembangunan pedesaan, kehutanan, dan manajemen konservasi sumberdaya alam lainnya.Untuk kawasan yang merupakan habitat satwa, jalur jelajah atau koridor satwa tidak direkomendasikan bagi restorasi 
Nurhalida Yogaswara, Edhi Martono, Djaka Marwasta -- Optimalisasi Peran Rimbawan Muda Dalam Pengelolaan Taman Nasional Gunung Ciremai Dan Implikasinya Terhadap Ketahanan Wilayah

(Studi di Balai Taman Nasional Gunung Ciremai Kuningan, Jawa Barat)

untuk peningkatan ekonomi, karena akan menimbulkan konflik kepentingan. Oleh karena itu, pada kawasan yang ditemukan bukti-bukti keberadaan satwa yang kondisinya sudah terdegradasi diprioritaskan direstorasi untuk tujuan pemulihan fungsi ekologi sebagai habitat satwa.

Melihat paparan faktor-faktor untuk mengukur capaian pengelolaan kawasan TNGC implikasinya terhadap ketahanan wilayah dirasa belum adanya sinergitas antara aspek ekologi, ekonomi dan sosial budayanya. Terwujudnya ketahanan wilayah baik dari desa sekitar kawasan TNGC maupun dari kawasan TNGC itu sendiri jika terdapat keseimbangan di masing-masing aspek. Ketika salah satu elemen tersebut tidak seimbang, maka akan terjadi ketidakseimbangan lingkungan. Dengan optimalnya pengelolaan TNGC akan memberikan kontribusi penting bagi konservasi keanekaragaman hayati dan ekosistemnya, seperti dalam membantu menumbuhkan tenaga kerja dan menambah pendapatan daerah dari sektor pariwisata alam serta dari wilayah kawasan TNGC pun terjaga kelestariannya fungsi SDA yang ada di dalamnya berfungsi secara optimal.

\section{SIMPULAN}

Berdasarkan penjelasan di atas dapat ditarik simpulan sebagai berikut.

Pertama, terkait optimalisasi peran rimbawan muda dalam upaya pengelolaan kawasan konservasi TNGC tampaknya masih berbenturan dengan kebutuhan ekonomi masyarakat yang belum sepenuhnya tercukupi dengan beralih profesi menjadi pengelola wisata dan jasa lingkungan sejak Gunung Ciremai di tetapkan sebagai Taman Nasional. Demi mewujudkan keseimbangan antara kepentingan pengelolaan kawasan konservasi dan pembangunan masyarakat belum sepenuhnya optimal. Potensi kawasan memang sebagai penghasil jasa lingkungan dan wisata alam. Dengan bertambahnya jumlah penduduk yang tinggi sehingga membuat kebutuhan Sumber Daya Alam pun meningkat pula.

Kedua, dalam proses penunjukan kawasan Taman Nasional Gunung Ciremai untuk membenahi pengelolaan hutan di Kabupaten Kuningan terjadi benturan inisiatif dengan masyarakat sipil, yang sebagian wilayah hutannya tercakup ke dalam TNGC. Agar kepentingan-kepentingan lokal dapat terwadahi dan tersampaikan dalam upayaupaya pencapaian tujuan akhir pembangunan Taman Nasional, maka pemanfaatan ruang dan lahan di kawasan TNGC dilaksanakan secara partisipatif bersama masyarakat desa sekitar. Dalam hal ini secara teknis di lapangan karena rimbawan memiliki pengetahuan manajemen hutan maka masyarakat sekitar perlu disadarkan terhadap pentingnya memelihara dan melindungi sumberdaya hutan dan mendukung konsepsi pemanfaatan SDH tersebut berdasarkan asas kelestarian hutan. Memberikan pemahaman bahwa dengan sistem pengelolaan taman nasional mampu melindungi, melestarikan dan memanfaatkan secara lestari sumber daya alam hayati yang ada dan ekosistem Gunung Ciremai secara optimal, sehingga dapat meningkatkan kesejahteraan masyarakat.

Ketiga, terkait optimalisasi peran rimbawan muda implikasinya terhadap ketahanan wilayah masih terdapat ketidakseimbangan di masing-masing aspek. Ketika salah satu elemen tersebut tidak seimbang, maka akan terjadi ketidakseimbangan lingkungan. Pengelolaan hutan kawasan selayaknya diarahkan kepada 
terpeliharanya keanekaragaman hayati yang ada dalam sumberdaya tersebut supaya dapat menunjang sistem kehidupan masyarakat saat ini dan di masa yang akan datang. Tidak hanya sekedar mampu menghasilkan produk atau jasa namun diharapkan lebih memperhatikan terjaminnta kelestarian ekosistem sumberdaya tersebut. Sementara itu, hutan lindung dan hutan konservasi harus dipelihara eksistensinya agar berfungsi secara optimal, karena dalam beberapa tahun terakhir prospek untuk pemanfaatan sumberdaya hutan lebih cenderung kepada kegiatan eksplorasi. Dalam kaitan ini, peranan kegiatan perlindungan hutan dan konservasi alam perlu ditingkatkan sehingga pemanfaatan keanekaragaman hayati hutan secara berkelanjutan dan mendorong regenerasi hutan secara alami. Pengelolaan Taman Nasional dikelola berdasarkan kajian aspek-aspek ekologi, teknis, ekonomis, dan sosial budaya yang ada di setiap daerah masing-masing di Indonesia, sebagai upaya pengawetan keanekaragaman jenis tumbuhan dan satwa beserta ekosistemnya, perlindungan, serta pemanfaatan kawasan untuk pembangunan nasional.

\section{DAFTAR PUSTAKA}

Adi, Rianto, 2008, Metode Penelitian Sosial dan Hukum, Jakarta: Yayasan Obor.

Haeruman Js, H, 2005. Paradigma Pengelolaan untuk Menyelamatkan Hutan Indonesia: Membangun Etika Pengelolaan Hutan Lestari, Jurnal. Bogor: Fakultas Kehutanan IPB.

Hidayat, Herman. 2015. Pengelolaan Hutan Lestari: Partisipasi, dan Konflik. Jakarta; Yayasan Pustaka Obor Indonesia.

Milles, M.B. and Huberman, M.A. 1984. Qualitative Data Analysis. London: Sage Publication.
Naim, Mohammad, 2011. Hutan, Kehidupan dan Kepemimpinan Rimbawan, Yogyakarta: Penerbit Cakrawala.

Soendjoto, M.A dan A. Kurnain, 2010, Pengelolaan Sumber Daya Alam dalam Perspektif Kesejahteraan dan Keberlanjutan, Banjarmasin: Universitas Lambung Mangkurat Press.

Sunardi, R.M., 1997, Teori Ketahanan Nasional, Jakarta: Himpunan Alumni Studi Ketahanan Nasional (HASTANNAS) , 2004, Pembinaan Ketahanan Bangsa Dlam Rangka Memperkokoh Keutuhan Negara Republik Indonesia, Jakarta: PT Kuaternita Adidarma.

\section{Peraturan Perundangan}

Undang-undang Nomor 5 Tahun 1990 Tentang Konservasi Sumberdaya Alam Hayati Dan Ekosistemnya

Peraturan Pemerintah Nomor 18 Tahun 1994 Tentang Pengusahaan Pariwisata Alam di Zona Pemanfataan Taman Nasional

Peraturan Pemerintah (PP) Nomor 68 tahun 1998 tentang Kawasan Suaka Alam dan Kawasan Pelestarian Alam

Keputusan Menteri Kehutanan Republik Indonesia Nomor 424/Menhut-II/2004 tanggal 19 Oktober 2004 Tentang Perubahan Fungsi Kawasan Hutan Lindung pada Kelompok Hutan Gunung Ciremai

Peraturan Menteri Kehutanan Nomor: P.52/ Menhut-II/2009 Tanggal 27 Juli 2009 Tentang Perubahan Kesatu Atas Peraturan Menteri Kehutanan Nomor P.03/MenhutII/2007 Tentang Organisasi dan Tata Kerja Unit Pelaksana Teknis Taman Nasional

Peraturan Daerah Nomor 38 Tahun 2001 tentang Rencana Umum Tata Ruang Gunung Ciremai. 
Nurhalida Yogaswara, Edhi Martono, Djaka Marwasta -- Optimalisasi Peran Rimbawan Muda Dalam Pengelolaan Taman Nasional Gunung Ciremai Dan Implikasinya Terhadap Ketahanan Wilayah (Studi di Balai Taman Nasional Gunung Ciremai Kuningan, Jawa Barat)

Peraturan Daerah Pemerintah Kabupaten

Kuningan Nomor 38 Tahun 2002 tentang Rencana Umum Tata Ruang Gunung Ciremai

Perda Provinsi Jawa Barat Nomor 6 Tahun 2003 Tentang Rencana Tata Ruang Wilayah Provinsi Jawa Barat.
Dokumentasi

Statistik Balai Taman Nasional Gunung Ciremai Tahun 2015

Renstra Balai Taman Nasional Gunung Ciremai 2010-2014 